\title{
Insights on the Behavior of Imidazolium Ionic Liquids as \\ Electrolytes in Carbon-based Supercapacitors: an Applied \\ Electrochemical Approach
}

Paulo F. R. Ortega ${ }^{*}$, Garbas A. dos Santos Junior ${ }^{\mathrm{b}}$, João P. C. Trigueiro ${ }^{\mathrm{d}}$, Glaura G. Silva ${ }^{\mathrm{b}}$, Noemí Quintanal $^{\mathrm{a}}$, Clara Blanco ${ }^{\mathrm{a}}$, Rodrigo L. Lavall ${ }^{\mathrm{b}}$, and Ricardo Santamaría $\mathrm{a}^{{ }^{*}}$
a. Instituto Nacional del Carbón, INCAR-CSIC, Apdo. 73, 33080-Oviedo, Spain
b. Departamento de Química/ICEx, Universidade Federal de Minas Gerais, Av. Antônio Carlos, 6627, Pampulha, CEP 31270-901, Belo Horizonte - MG, Brazil

c. Departamento de Química, Centro Federal de Educação Tecnológica de Minas Gerais, Av. Amazonas, 5253 Nova Suíça, CEP 30421-5169, Belo Horizonte - MG, Brazil

d. Instituto Federal de Minas Gerais - Campus Betim, Rua Itaguaçu, 595, São Caetano, CEP 32677-562, Betim MG, Brazil

\section{*Corresponding authors.}

E-mail address: pauloortega@cefetmg.br (Paulo F. R. Ortega), rodrigo.lavall@qui.ufmg.br (Rodrigo L. Lavall), riqui@incar.csic.es (Ricardo Santamaría). 


\section{Description and calculation of the electrochemical parameters}

All the electrochemical measurements were performed in a BioLogic VMP3 (USA) device at $25{ }^{\circ} \mathrm{C}$. Galvanostatic tests were performed at different current densities $\left(50-500 \mathrm{~mA} \mathrm{~g}^{-1}\right)$ and at a cell potential of 3.0 $\mathrm{V}$. The cell capacitance $\left(\mathrm{C}_{\text {cell }}\right)$, energy density $\left(\mathrm{E}_{\mathrm{sp}}\right)$, power density $\left(\mathrm{P}_{\mathrm{sp}}\right)$, equivalent series resistance $(E S R)$, and coulombic efficiency $(\varepsilon)$ values were calculated by integrating the galvanostatic discharge profiles and subtracting the ohmic drop by applying equations $1-5$, respectively.

$$
\begin{gathered}
C_{\text {cell }}=\frac{2 I\left(\int V d t\right)_{\text {discharge }}}{\left(m_{+}+m_{-}\right) V_{\text {discharge }}^{2}} \\
E_{S p}=\frac{I\left(\int V d t\right)_{\text {discharge }}}{\left(m_{+}+m_{-}\right)} \\
P_{s p}=\frac{E}{\Delta t_{\text {discharge }}} \\
E S R=\frac{V_{\text {max }, \text { charge }}-V_{\text {discharge }}}{I} \\
\varepsilon=\frac{\Delta t_{\text {discharge }}}{\Delta t_{\text {charge }}} \times 100
\end{gathered}
$$

where $\mathrm{I}$ is the current applied, $\mathrm{V}$ is the cell potential, $\mathrm{m}_{+}$and $\mathrm{m}_{-}$are the mass of active material in the positive and negative electrodes, respectively, $\mathrm{V}_{\text {max,charge }}$ is the maximum cell potential reached during charging, $\mathrm{V}_{\text {discharge }}$ is the maximum cell potential discounting the ohmic drop, and $\Delta \mathrm{t}_{\text {discharge }}$ is the discharge time.

The specific capacitance of each electrode $\left(C_{+}\right.$or $\left.C_{-}\right)$was calculated by integrating the discharge profile (potential vs. time) of each individual electrode by means of equations 6 and 7. The equivalent series resistance $\left(E S R_{\text {electrodes }}\right)$ for the electrodes were determined from the ohmic drop at the beginning of the discharge profile and calculated by means of equation 8 .

$$
\begin{aligned}
& C_{+}=\frac{2 I\left(\int U_{+} d t\right)_{\text {discharge }}}{\left(m_{+}\right) U_{+}^{2} \text { discharge }} \\
& C_{-}=\frac{2 I\left(\int U_{-} d t\right)_{\text {discharge }}}{\left(m_{-}\right) U_{-}^{2} \text { discharge }}
\end{aligned}
$$




$$
E S R_{\text {electrode }}=\frac{U_{\text {max, charge }}-U_{\text {discharge }}}{I}
$$

where $U$ is the electrode potential, $U_{\text {max,charge }}$ is the maximum potential reached by the electrode during charging, and $\mathrm{U}_{\text {discharge }}$ is the maximum potential discounting the ohmic drop.

\section{Galvanostatic curves for the cell constructed with MWCNT and EMITFSI}

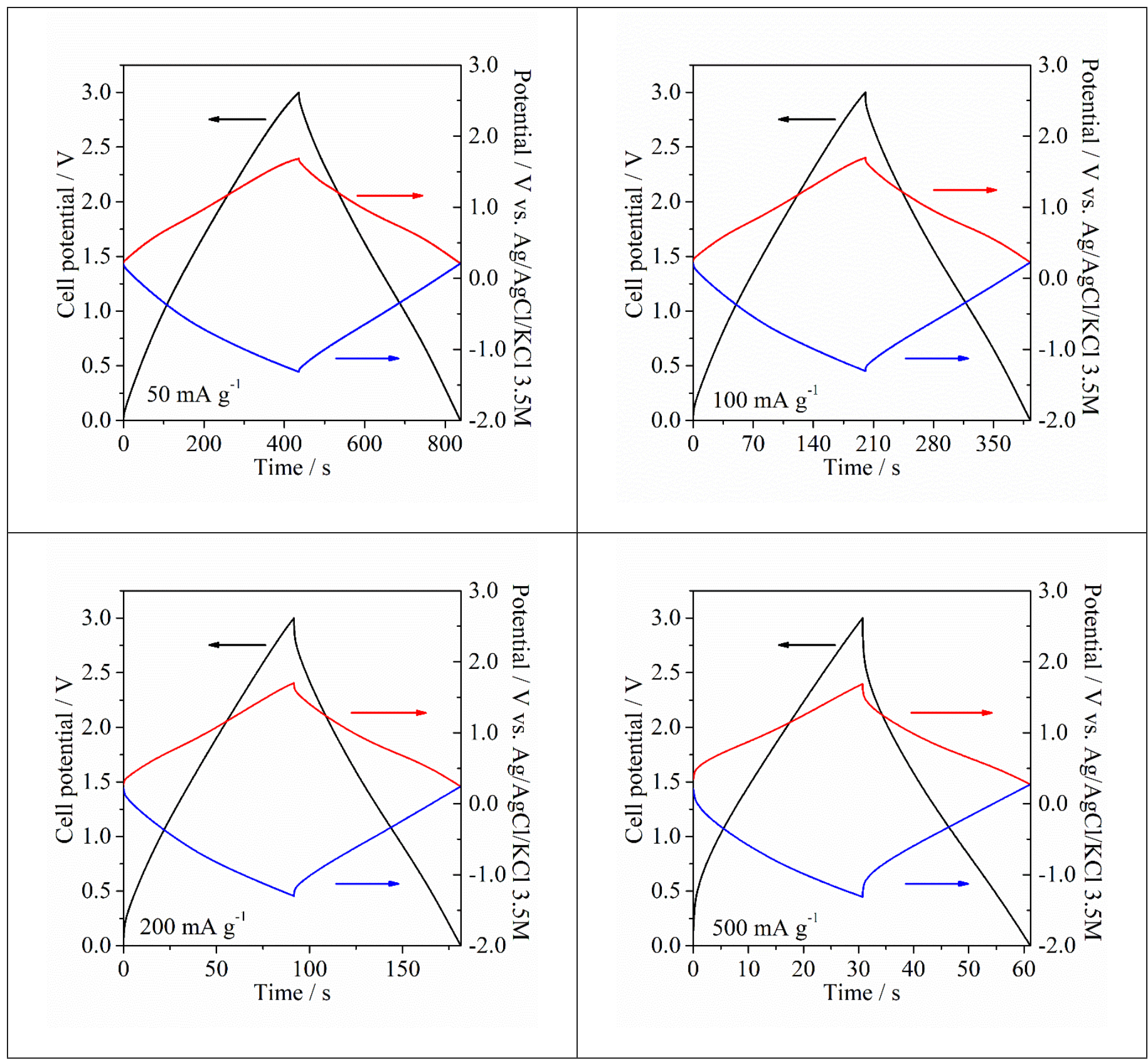

Figure S1. Galvanostatic curves for the cells constructed with MWCNT and EMITFSI at 3.0 V and at different current densities $\left(50,100,200\right.$ and $\left.500 \mathrm{~mA} \mathrm{~g}^{-1}\right)$. 


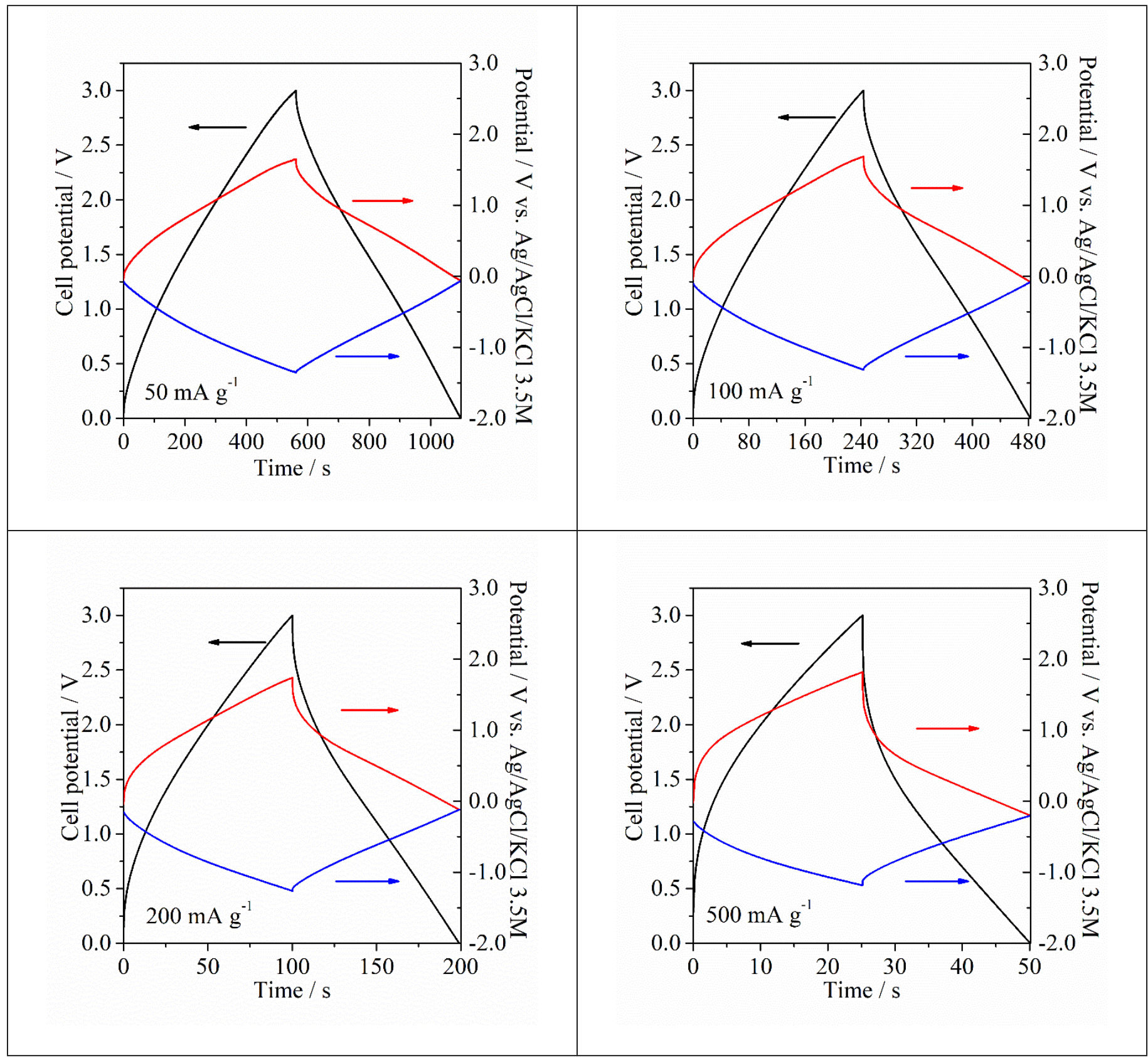

Figure S2. Galvanostatic curves for the cells constructed with GRO and EMITFSI at 3.0 V and at different current densities (50, 100, 200 and $\left.500 \mathrm{~mA} \mathrm{~g}^{-1}\right)$. 


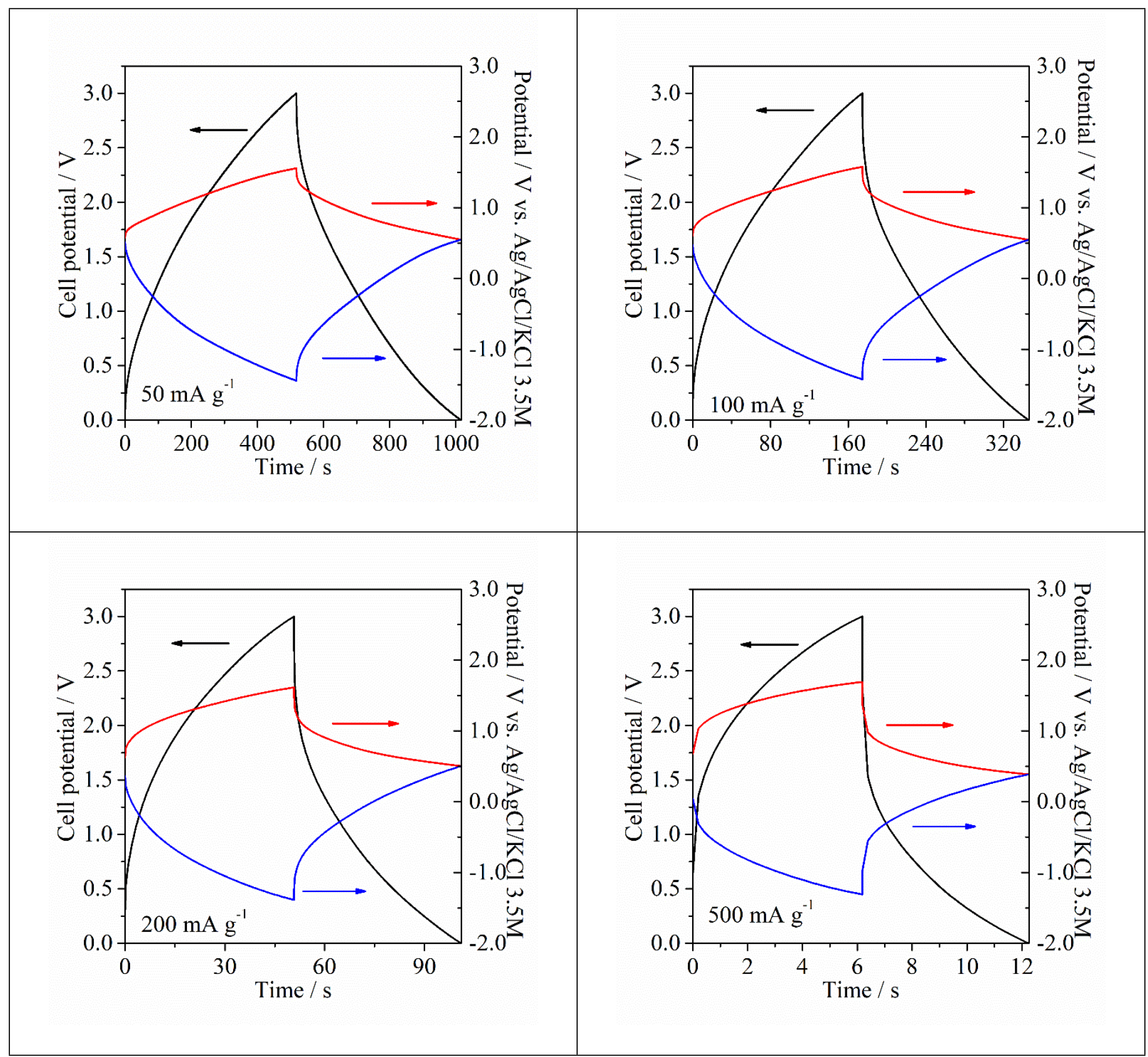

Figure S3. Galvanostatic curves for the cells constructed with $\mathrm{AC}$ and EMITFSI at $3.0 \mathrm{~V}$ and at different current densities $\left(50,100,200\right.$ and $\left.500 \mathrm{~mA} \mathrm{~g}^{-1}\right)$. 


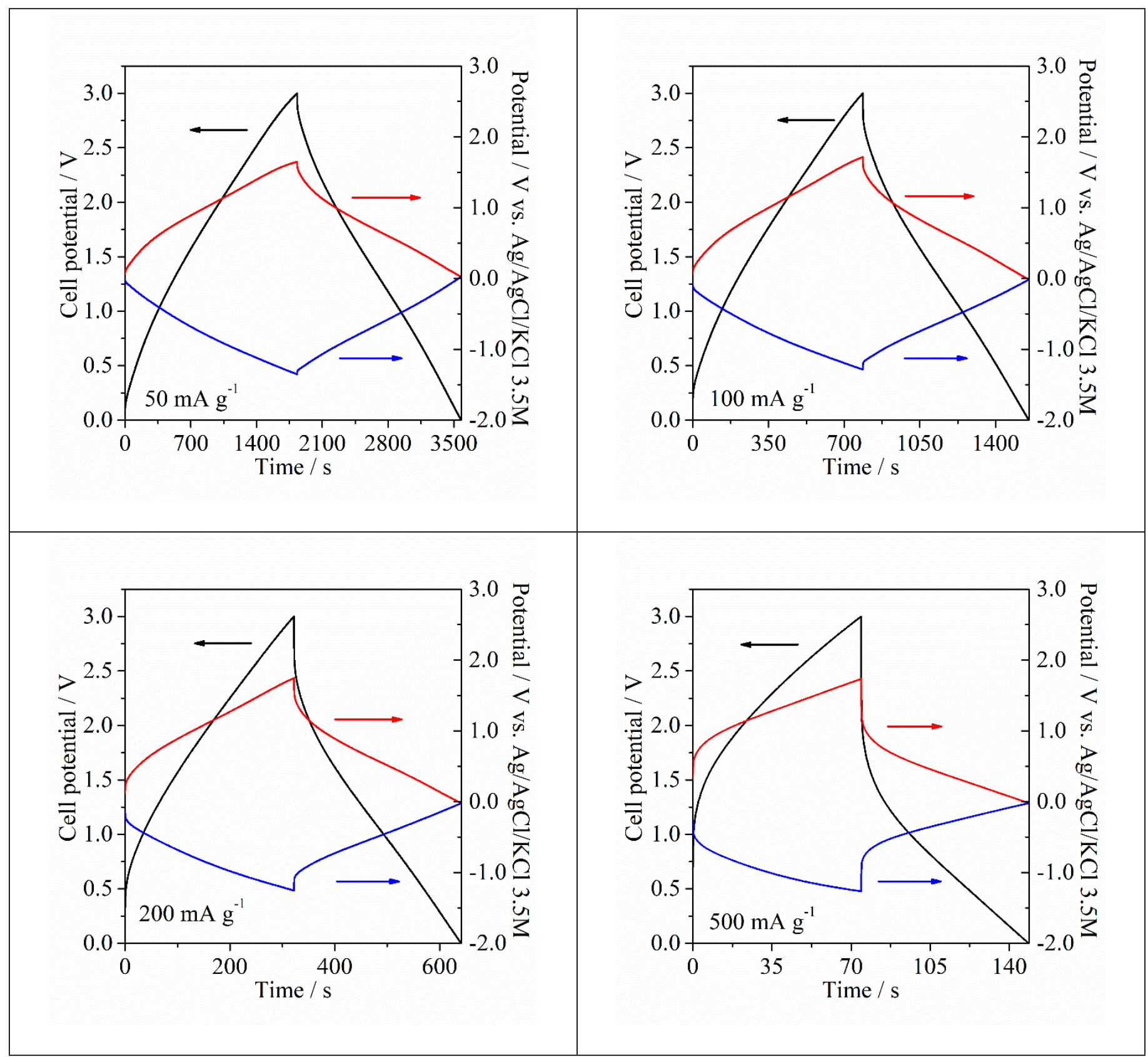

Figure S4. Galvanostatic curves for the cells constructed with MES and EMITFSI at 3.0 V and at different current densities $\left(50,100,200\right.$ and $\left.500 \mathrm{~mA} \mathrm{~g}^{-1}\right)$. 


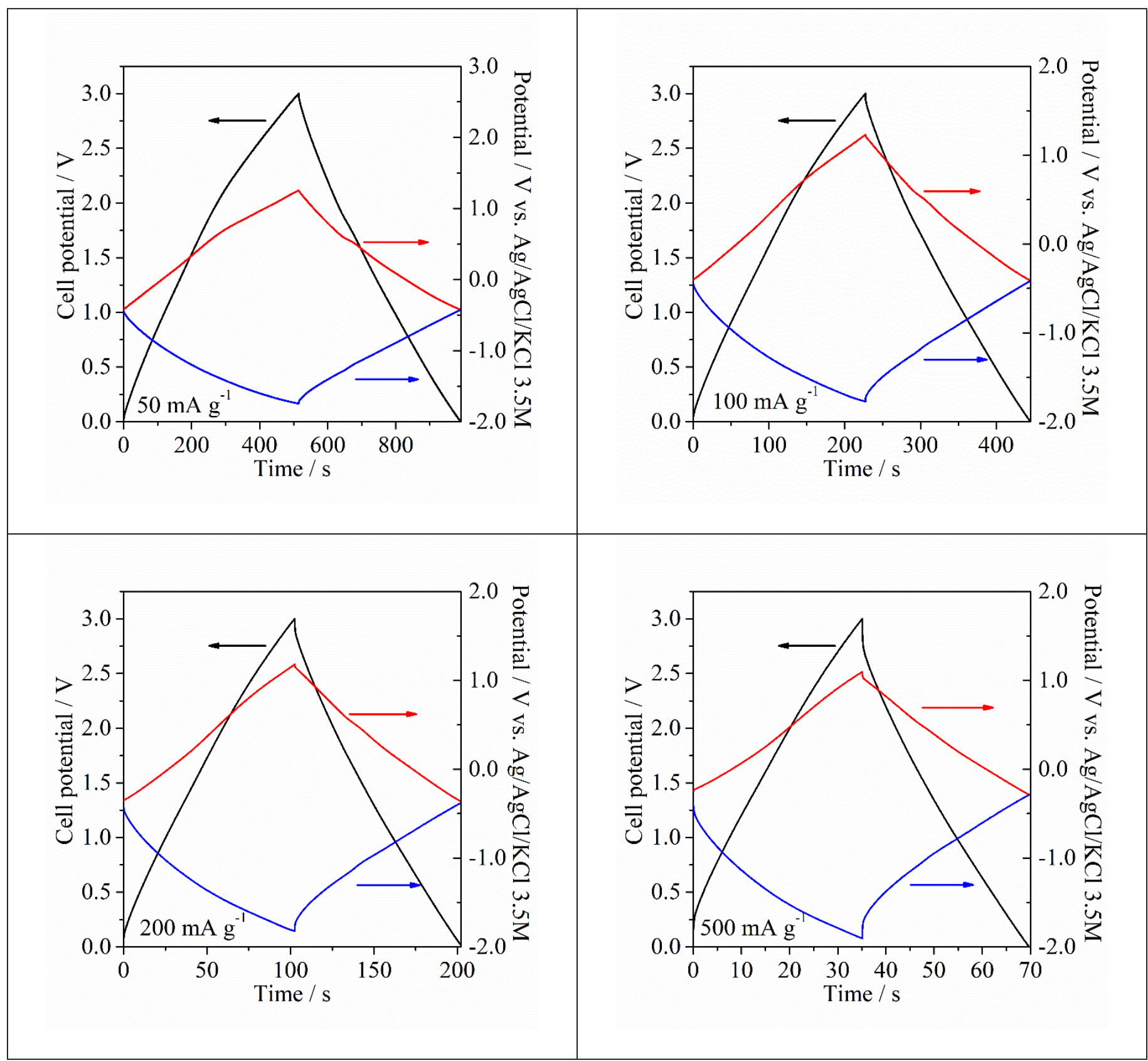

Figure S5. Galvanostatic curves for the cells constructed with MWCNT and $\mathrm{EMIBF}_{4}$ at $3.0 \mathrm{~V}$ and at different current densities (50, 100, 200 and $\left.500 \mathrm{~mA} \mathrm{~g}^{-1}\right)$. 


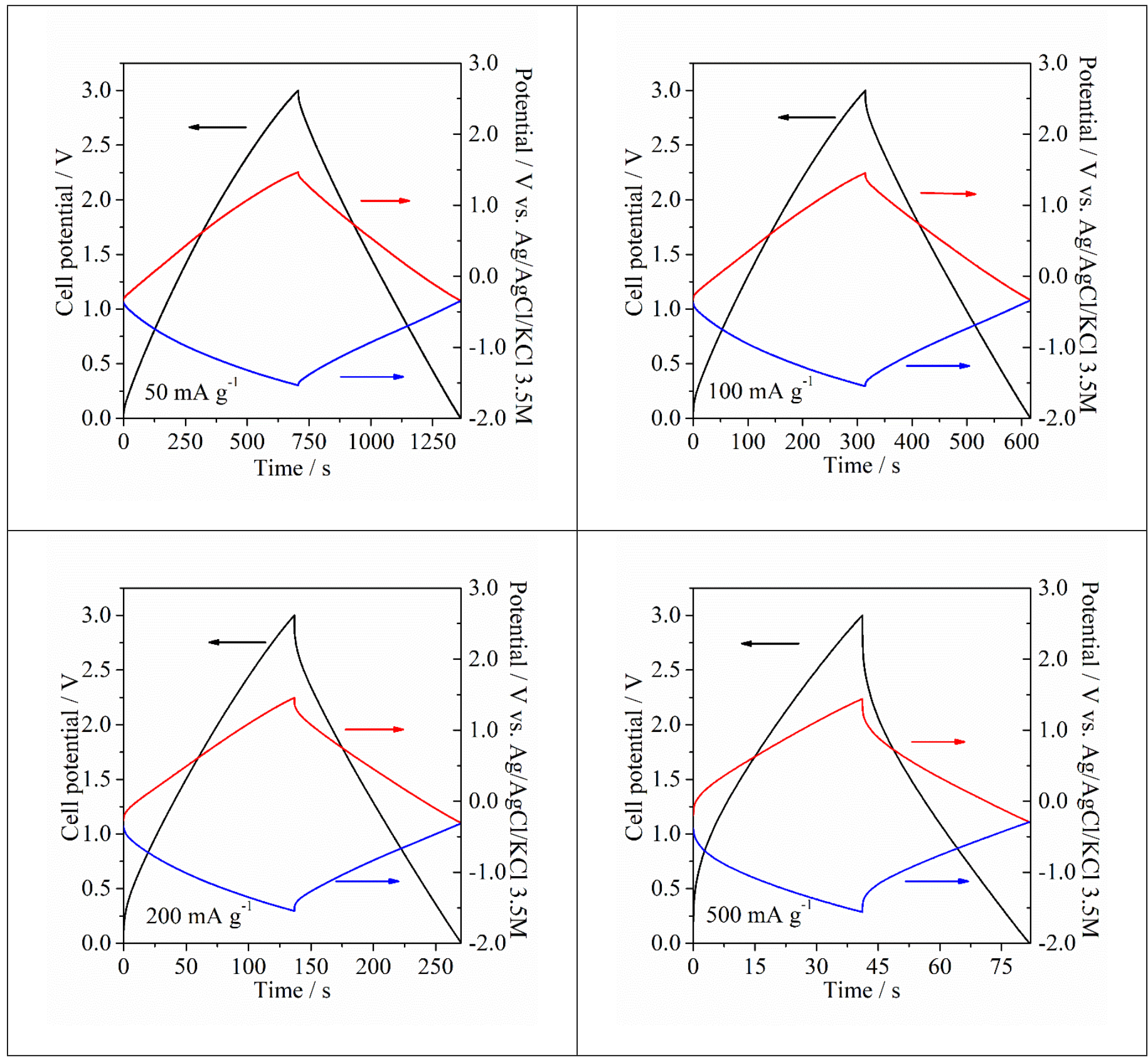

Figure S6. Galvanostatic curves for the cells constructed with GRO and $\mathrm{EMIBF}_{4}$ at $3.0 \mathrm{~V}$ and at different current densities (50, 100, 200 and $\left.500 \mathrm{~mA} \mathrm{~g}^{-1}\right)$. 


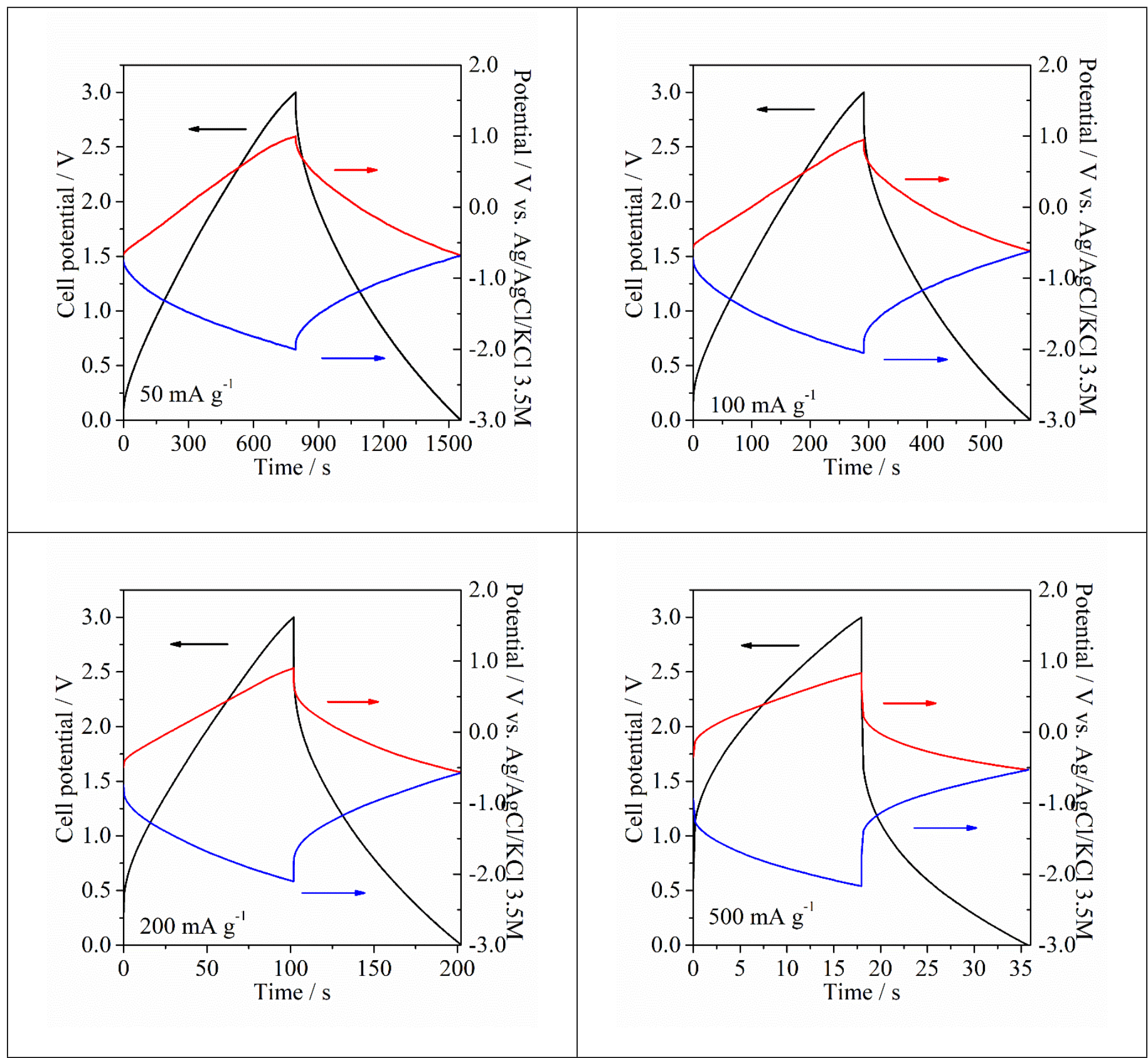

Figure S7. Galvanostatic curves for the cells constructed with $\mathrm{AC}$ and $\mathrm{EMIBF}_{4}$ at $3.0 \mathrm{~V}$ and at different current densities (50, 100, 200 and $\left.500 \mathrm{~mA} \mathrm{~g}^{-1}\right)$. 


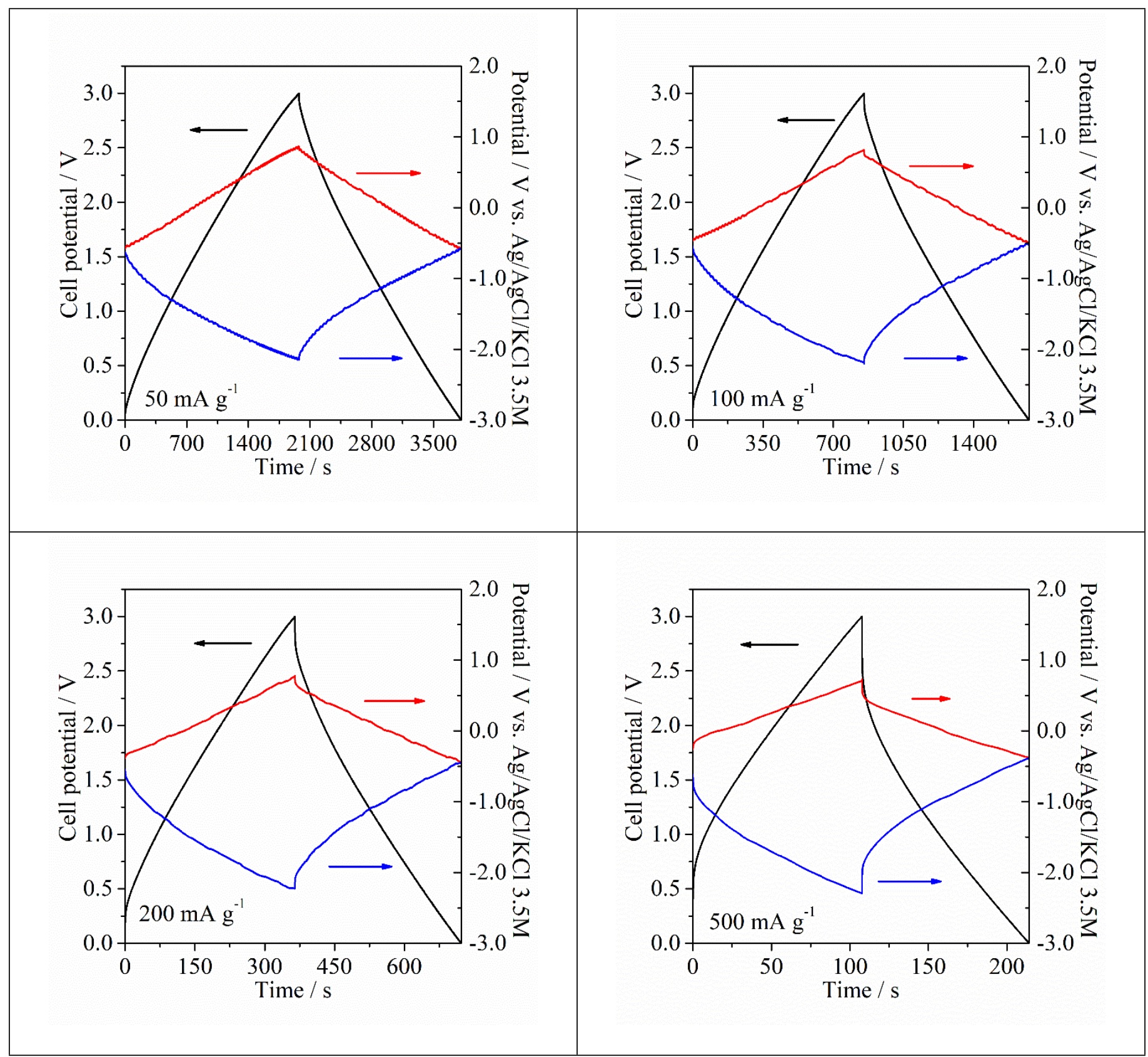

Figure S8. Galvanostatic curves for the cells constructed with MES and $\mathrm{EMIBF}_{4}$ at $3.0 \mathrm{~V}$ and at different current densities $\left(50,100,200\right.$ and $\left.500 \mathrm{~mA} \mathrm{~g}^{-1}\right)$. 